Portland State University

PDXScholar

$1-1-1965$

\title{
The nationalization of education in England : Fabian influences on the Education Bill of 1902
}

Marguerite McBurney Marks

Portland State University

Follow this and additional works at: https://pdxscholar.library.pdx.edu/open_access_etds Let us know how access to this document benefits you.

\section{Recommended Citation}

Marks, Marguerite McBurney, "The nationalization of education in England : Fabian influences on the Education Bill of 1902" (1965). Dissertations and Theses. Paper 404.

https://doi.org/10.15760/etd.404

This Thesis is brought to you for free and open access. It has been accepted for inclusion in Dissertations and Theses by an authorized administrator of PDXScholar. Please contact us if we can make this document more accessible: pdxscholar@pdx.edu. 
AN ABSTRACT OF THE THESIS OF

Marguerite Marks

(Candidate's name) for the Master of Science in Teaching

Date thesis is presented: May 24, 1965 (date)

Title: The Nationalization of Education in England

Fubtan Influence on the Euncation B111 of 1902

Abstract approved:

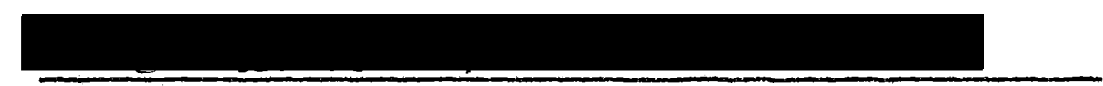

(Thesis Adviser) 
The purpose of this paper was to prove that the Fabians were a political pressure group and that Fablan methods were responsible for the enactment of the 1902 Education Act that nationalized education In England. Also, that Sidney Webb played a far greater and more significant part in the formulation of the actual Bill than did Robert Morant, who is usually credited as the person responsible for the Bill.

It seemed to we that it was necessary to trace the evolving educational system in England; therefore, I made the arbitaary decision of beginning with the "Sunday school" which I vlew as the beglnning of "education for al1." It was necessery to select the elements of the social and political affairs that I felt pertained to the subject as I dealt with 1t. There are situations that have been omitted, and there were times when it was difflcult not to digress Into areas of lesser signiflcance. Therefore, the paper is divided Into two sections: the first section traces the historical pattern of the emergence of education for the comon people; the second section is devoted to the active involvement of the Fablens and covers a much shorter epan hiatorically.

The first part of the paper traces the dual system of education that consisted of the "board" schools, which date from 1870, and the "voluntaxy" schools. Although the "voluntary" Bchools are as old as the Christian Church In England, the development of the "voluntary" system, for the purpose of this paper, begins at the time 
of the Wesleyan rift with the Church of England. It was from that time that the voluntary chools developed into "denominational" schools and, as a consequence, reflect the power struggle that developed between the landed gentry and the entrepreneurs as a result of industrialization.

Throughout the nineteenth century, the ever extending franchise brought with it an Increasing demand for changes in the educational systam in England. The second part of this paper deals wth the manner in which the Fabians, as a pressure group, Influenced the emactment of the 1902 gducation Act. It 16 my thes 1 s that the basic structure of the act was outlined originally by Sidney Webb and that Fabtan Iract No. 106 was the primary model used by the Conservative goverment in formulating the B111. Inasmuch as the educational system of England is still in the process of fulfilling the suggestions contalned in the Act of 1902, perhaps from an historian's standpoint, it is too early to be definitive concerning the role of the rabians. Nevertheless, enough naterial about the Fablans is avallable to prove their Influence in securing the enactment of the B111. Much more work needs to be done on the Fabians. They were a remarkable group of men and women whose Impact, in my judgment, is far greater than we are able, at present, to measure.

Party politics are of recent origin and the Fablans belong to what some political sclentists have termed the "third house" In the leglslative process. The Fabiang are a pressure group and the activity they carried on In regaxd to the Education Act, In my 
view, was a form of lobbying. It is fran this viewpoint that I have dealt with the Fabians in this paper. 
ARTOVED:

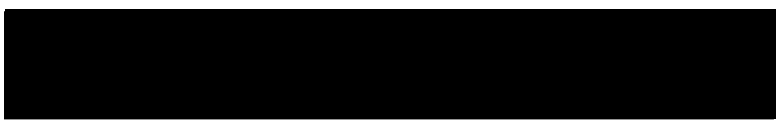

Thesis Advisax

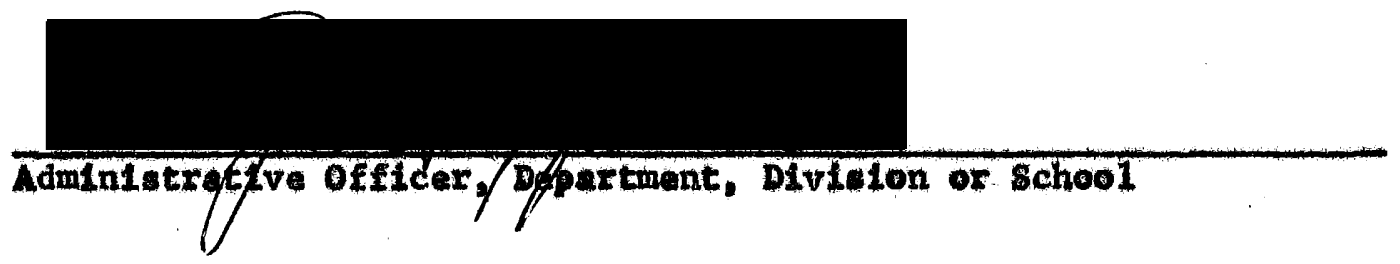

For the Graduate counc1I

Date thesis is presented: May 24, 1965 
APPROVED:

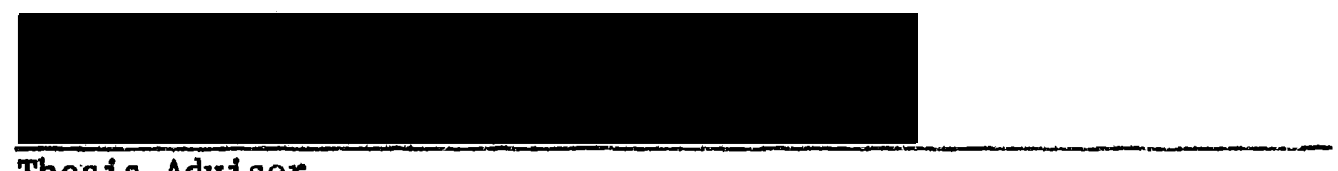

Thesis Adviser

Administrative Officer, Department, Division or School

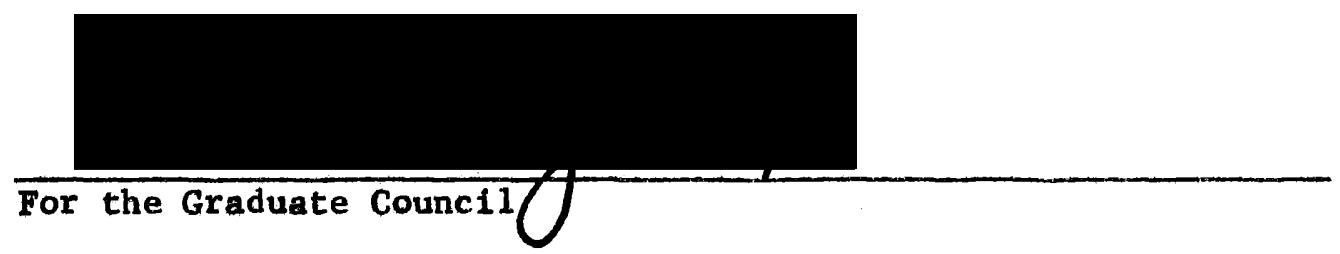

Date thesis is presented: May 24, 1965 
THE MATIONALIZATION OF EDUCATION IN ENGLAND

Fabian Influences on the Education Bill of 1902

by

Marguertte Marks

\author{
A THESIS \\ Bresented to the Departwent of Hidtory \\ and the Graduate Counc11 of Portland state College \\ In partial fulfillwent \\ of the requirements for the deyree of \\ Haster of aclence in Teaching \\ June 1965
}

PORTLAND STATE COLLEGE 
How far the acquiescence of the public in the enormous extension of state activity and control has been faclittated by the Insidious preaching and permeetion of the Fablans 18 question which it is easy to aek, but which no wloe man will venture to answer. 
PART OAE: The Beginnings of zducation for A11 
Toward the lattex part of the nineteenth century, concerned

Engliahmen recognized that the pollcy of "muddling through" no longer was tenable in regard to meeting the educational needs for the citizenry of England if their country was to malnteln her position of leadership among the Industriallaing nations. Characterlatics of England on the threshold of the twentieth century were

Nine hundred yenre of freedom from Invasion, Individual liberty, a conservative established church, the economic doctrine of lalssen falre, and relatively rigid sociel classes. The upper classes were powerful and influent1al. A strong middle clase of businessmen, prosperous farmers, hopkeepers, and professional men was often referred to as "the backbone of the country."

The educational system in the nineteenth century followed this general orgenization of soclety. The "Great Public Schooly," which were really wealthy and exclusive church and private schools, catered for the ons of the upper and middle clesses. Their products had a virtunl monopoly of 
places at Oxford and Cambridge universitie and subsequently of positions in the civil service and the professions.1

Thus it was observed that England had a pollcy toward education in which there was no seablance of effictent planning and England, the country that had given birth to Industrialization, was falling behind Anerica, Cermany, and France in ut1lizing the machinexy of the state for the purpose of creating a national syotem of education. Amarlca, for example, had used the power of the federal government to assist the establishment of the means of providing education for her westward moving populetion with the enactment of the Northwest Ord1nances of 1785 and 1787 . On the continent, the General Code of 1794 had definttely made Prubsian schools state Institutions; and in France, the French Revolution had been followed by the centrallzed sutocracy of Napolaon whose adainistrative efficiency atrengthened the Influence of the state itself. Thus, as early a 1831, following a report made by Victor Cousin, the Minister of Bducation, Guizot secured leglslation that firmly establiehed the lementaxy oyutem of education In France as the reaponsibllity of the state. Actually, on the continent, revolution tended to destroy the old educational foundetions controlled by the Church and to replace them by ate aystem of achools. In Bngland, however, there remalned a deep-seated mistrust of stete Interference; a supicion that stemmed from as far back as the CIvil War period when the propertled classes, having won their struggle with the

${ }^{1}$ John Franclo Cramer and George Stephenson Browne, Contemporary Bducation (New York: Harcourt, Brace and Wor1d, 1956), p. 57. 
monarchy, remalned adamant in their determination not to risk submitting right to an arbitrary governmant.

But with the growth of Industry, new phage of human existence was beginning, a phase without precedent in history. Alvays, previously, there had been an educated few; never an educated miss. Indeed, never before the age of industrialisetion was it necessary that education be provided on such a wide acele and for all segmente of soclety. As the chine made it possible to produce more goods and provide services, 1t baceme Increasingly apparent that education was neceselty rather than a luxury for the few. The machlne age Increasingly demanded tralned techniclans, englneers, chemleks, foreman, clerks, accountants, and these posttions required an lementary education at lesst in such areas os reading, writing and arithmetic.

No doubt in the thoughts of those who contributed to the gradual evolution of the national eystem of education in Bngland, motivations were varled and mixed. Closely Intertwined, throughout the entire period of formation was a religlous motive beed on a woral and ethical foundation of sincere efforts to ralse the general level of conduct; a political motiva designed to cope with the situation of providing an education for those to whom the extension of the franchlse was granting Increased political power; and a natlonal motive to strengthen patrlotiam as athod of providing the malnetay for milltary and Industrial might.

A scrutiny of the lendmarks in the nationalization of education In England during the ninateenth century leade one to conclude, however, that practical utility wae a more potent factor than idealiam. 
Certalnly, as it becane more and more evident that at lesot an elementary education would be useful, Indead, essentiel, for the comoner in the everyday takk of oarning a living, so it became increasingly clear that the state would have to be the provider for an effective oystem. This 10 reflected in the opening etatement made by J. E. Forater In Parliament as he introduced the Blementary Education Act of 1870 :

We must make up the amellnese of our numbers by incrensing the intellectual force of the individunl. . . . We must not daley. Upon the speedy provision of elesentery education dependg our Industrial prooperity. It is of no use trying to glve technical teaching to our artians without elementary education; unoducated labourer are utterly uneducated-are for the most part, unokilled labourers, and if we have oux workfolk any longer ungk1lled, notwlthstanding their atrong sinews and determined energy, they wLII become over-matched in the competition of the world. I

W1th the passage of the Foreter Act in 1870, England established for the firot time in 1te history, ational system of elementary schoole. The passage of the b111 through Parllament evoked bitter opposition that centered on the role of the Church in providing education. Indeed, the baslc lssue was whether education was the province of the church or of the otate. Compounding the lavue, moreover, was the fact that two competing gystems of education, based on rellg1ous foundatlons, had developed during the nInateenth century--one provlded by the Church of England and the other product of the Nonconformats. The schools were known as "voluntary" schools and were an outgrowth of the "Surday School" movement that had opread rapldiy during the last quarter

${ }^{1}$ Hensard, vol. 199, co1. 465 , February $17,1870$. 
of the elghteenth century.

With the riog of industry, there hed bean a gravitection of people frow the land to the towns where chlldren answared the needs of the enctor1es for a cheap labor supply. The chlldren ware kept off the street by the finctortes during olx daye of the wak, but on Sundays, thatx widespread wantones led to the resctivating of Sunday schools: a cunton that had fallen Into dieuse although it remalned canon of the Church of Basland. The sunday echool revival, hovover, was etarted outalde the Church of Englend and found widepresd support from the ovangelletlc sects that had ben reavakenod by the rift batwen the Church of Ingland and the Hesloyen movement. 1

The sunday echoole, established late in the alghteenth century, ware the firat indication that "education for all wa a poselbility. Bafore the Sunday school, wth Ite voluntedr teachere who taught the Iaboring clavese how to read tho BLble, educutional agencles had been selectlve Inotitution for thoee who could afford to pay or who had the Intelligence enough to benetit from the abolatence of andowante or char1t1es. The Sunday achools werved a worthy puxpose in factory towne, but where there waro no factorles, and cornequently no need for chlld labor, achoole developad to meat the problem of keeplng the children off the etreete and out of mischlef. 2 It was for thls reason that the aystem of "voluntery" schoole developed In sngland early in the nineteenth century. One of the flrot weh schoole astabliahed by John Inenstar

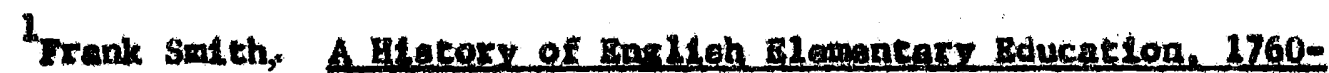
1902 (Iondon: Untveretcy of Iondon Prese, Led., 1931), pp, 47-49. 2IbLd.: pp. 60 and 70 . 
In roon in his father's house. It was so auccessful in terme of the number of students that the school outgrew 1to or1ginal quarters. Lancaster was a dowconfomite and his following cume from this group. The Church of England becane concerned wh Inncustex's success and set up a rival ayotem of schools undar the direction of Andraw Ball. In an outbreak of butility over the originntion of the monitorlal syotem in wich older atudents acted as inotructors for beglnnex as mean of coping with Increased enxollmants and the dearth of qualifled teachers, polltical overtones enqued wen Dlosenters, longstanding foes of the Church of Englend, sidad with Inncaster.

The monttorlal system appanied to the ruling class as an economic method for providing education for the commoners. Although the syatem recelved financlel support a a result, over increasing entolimant brought about an increasing need for school bulldings. Covernment assistance was sought in 1807 when B11 was Introduced in Paxllament proposing the aetting up of a national system of Ilementary education supported fram public funds. The BLII panged the Hoube of Comono, but it fatled in the House of Lorde, largely as a reault of unylelding opposition by representatives of the Church of Englend.

Meanwh1le, both the Church of England and organized Monconformity wexe in the process of becomins comalted to the swelling voluntary schools with the elm of providing the nation with a univarad oystem of Blementaxy education. In 1811, the National Soclety for Promoting the Education of the Roor in the Principles of the Eatabliahed Church throughout Bngland and Wales was formod for the purpose of eatablishing and mantalning schools for the comon people. The following year the Britioh 
and Forelgn School soclety, Nonconformiet organlzat1on, took over the vork of the Royel Lancseterian Soclety, non-denoninatlonal group that had been carrytag on the work of Lancaster.

Within twenty years these societies had provided, entirely out of voluntery contributions, numerous shools all over the country. It wes a remarkable echlevement; nevertholess, even wthin this perlod of exceptional activity it becume obvious to the discerning few that, despite the readinese with which the rich were eubseribing to this charlty-mes they ware alco to others--and deepite the devotion with which inmumerable persons, both prleata and laymen, ware glving themelves to the mork of establishing and winteining schools, voluntary effort could never itself cope with the glguntic task of schooling all the nation's children. And 80 the demend was pressed agaln and agatn for ald from public funds. 1

The extenoton of the franchige in 1832 brought an increase In the solicttude for the Ingtruction of the mases olnce for the firet time the growing lnduvtrial town, auch es Birminghem and Yanchester ware granted repreaentation in Parlimment. Conequently, the above numad socleties found Increased support in Farlimment for Covermment ald.

The and year reports of a Raxllementary countee under the chalrmanohip of Mched sadlex contalned firet hand accounts of the crualities wuffered by chlldren working in the fuctorled how the fear of belug late prompted then to arrive long before the warning bell; how they ware kept at their jobs long hours through the day and into the night, throutened with bodily harm by an overseers and how they often fall asloep at their work and by the timo they arrived hows, they were too tired to aet. The report contalned evidence of the lack of concern

1H. c. Dant. The Bducational System of Encland and Weles (London: Univeretty of Iondon Frese, 1961), Pp. 18-19. 
for unfaty equipment on the part of the factory owners. 1 As a result, In 1833 the Pactory Act put a halt to some of the "worst ev1l of the employment of children."2 The Act put a 11mitation of alght hours work for chlidren under thirteen years of age and children up to elghteen were Ilnited to twelve houra. In addition, children under thirteen were required to present, each Honday morning, a certiflcate to whow that they had been 1n echool for at least two houre day for the previous waek. 3

In July of the same year J. A. Roebuck noved from the floor of the Howne of Combons that some means be devlsed "for the untversal and national education of the whole people." Roabuck asealled the prevalling oplnion that education "conclota $[s] c, 7$ of reading and writing, with the occalonal incluston, by a otretch of 11berality, of arithmatic." He argued that "the training of the Intellectunl and moral qualltles of the Individual, and the preparation for aseful and virtuous mombershlp of aoclaty, was only the right conception" and he polnted out that "a national syatea" of education plenned on these lines, would produce a people "Industrlous, honat, tolerant and happy." Roabuck drew attention to the exmmples of Irance, Prusela, and America In pollcler regarding the proviaton of antonal aystem of education and he urged that the Governmant hed not only the negat1ve duty to "prevent ev11," It had the positive duty to promote good. For this reason, it was Roebuck's con-

Lox detalled excexpt from the Comitte heartugs, see: George H. Knoles and RIxford $\mathrm{X}$. Snyder. Rendings In Nentern Clulilination (Hew York: J. B. Llppincote Company, 1960), Pp. 565-582.

26. D. H. Cole and Raymond Rontgate. The Butteh Common People, 1746-1946 (New York: Barnes and Noble, 1961), P. 259.

3rank Smith, p. 143. 
tention that educetion ought to be regarded es one of the chief concerno of the nation. He stated:

In general terms, I would any that I would oblige by law, every child in Great Britain and Ireland, from, perheps ilx years of age to twelve yeare of age, to be a ragular attendant at chool. If the parente be able to give and actually do glve their children alsewhere sufficlent education, then they should wot be compelled to send them to the national echeol. If, however, they ahe sld bo unwilling to give then ouch inatruction, then the state ohould tep in and upply this want by compelifing the parent to send the child to the achool of the state. 1

Although Robbuck was forced to withdraw his motion, a few days later In the House of Commoar, lord Althorpe proposed:

That a Sum, wot exceeding 20,000 pounds, be granted to Hits Majesty, to be lesued in ald of Prlvate Subscriptions for the Erection of School Houses, for the Education of the Calldren of the Poorer Classes in Great Brituin, to the 31 t day of March 1834; and that the oald su be losued and pald without any fee or other deducation whatsoover. 2

The approprintion wes pased and the condttions for dietribution were Isewed tin a Treasury Minuta of August 30, 1833. The funde were to be used to butld schoole, on a matched basts, Inasmuch as local subacriptions of at least half the estimated cost were required before a governuent grent would be glven. Applications from large citleg and town were to recelve preference and elther the National Soclety or the Britioh and Forelgn School Society were required to support any application, and guarantee that the school would be malntained paxwanentry. 3

1Hangard, 3xd Sexted, $x$, July $30,1833$.

${ }^{2}$ Ibid. Xxt, August 5, 1833.

3rank smith, p. 140 . 
By 1839, the grant was Increased to 30,000 pounds. At that time, Lord John Russell felt It necessary to advise the queen to use the Royal Prerogative in creating a special department of the Privy Counc11 to adminlatex the Government grants for school bulldings alnce the passage of the grant had been heavily contested. Thus, by ordex In Counc11, a Comittee of the Privy Counc1l for Education was establiehed. The present Mintetxy of Education evolved from this comittee. 1

One of the firet acte of the newly formed complttee was to stipulate that bullding granta, in the future, automatically carried the right of State Inepection. Thus the Minutes of the Comalttee of Council for September 24, 1839, state:

The right of Inapection will be required by the comittee in all cases; the Inopectors, authorleed $[$ blc $\bar{J}$ by Har Majeaty In Counc11, will be appolnted from time to time to vialt schools to be henceforth alded by public money: the inspectors w111 not interfere with the religlous instruction, or disc1pline, or management of the achool, it being their object to collect facts and Informetion, and to report the result of their Inspections to the comittee of counc11.2

Immediately, through the National soclety, the Church of Inglend volced opposition to this directive, maintalning that it wes the right of the Church to Inspect its own schools. Further, within the competing denominational bodles there forwed obtter antagonlom agalnat any form of State Intervention in education that was a troublesome area of friction.

Not less difficult to contend with were the hostility of many industrialists to any extenaion of elementaxy education (which diminished thelr supply of cheap labour), and the governmental

1 cramer, p. 62.

2s. J. Curtls and K. B. A. Boultwood. An Introductory Hilatory of Rducation since 1800 (London: Dnlversity Tutorial Press, Ltd. 1960, Second Edition 1962), Pp. 60-61, ae quoted in th1s source. 
parsimony which denanded that any auch education should be provided at the cheapest possible rate. The confused struggle between these warring factions persisted for many years, serlously retarding and stunting the growth and development of elementaxy education. Industry, alded and abetted by parents gnatched children of a tender age from the schoola--1f indeed they were allowed to enter them; goverwental econotay cored a dreadful triumph . . . then by the Revised Code of 1862 it cut down the curriculum of the Blementary schools to the bare ' $3 \mathrm{Rs}^{\prime}$; denominational pride and prajudices frustrated any hope of a untted voluntary affort; and all these forces hindering progrese tewards the national aystem of aducation which the country desparately necded were powerfully aupported by the prevelent political and economic doctrine of lalssez falre; . . 1

Mid-point in the century, however, there vat a mounting concern about the increasing competition the British industrias were experiencing from abroad; the success of which was as a result of the efficlency of state oupported vocational education especially in Prussia, France, and Bwitzerland. The reoult was that between 1861 and 1864 the Parliamentary appointed clarendon Comasion Inquired into the curriculum, instruction, and management of nine puhlle schools: 3ton, Winchester, Charterhouse, st. Paul'a, Merchant Taylor:' Herrow, Wentwinater, Rugby, and Shrewsbury. With this action state intervention had extended into the affairs of the endowed gchoole and reaulted in critician of the Inadequacy of the classical curriculum for the sone of the factory owners in the Industrial areas who hed been gIven politlcal power by the Reform Act, 1830 . The clue "to the Baglish attitude to class and soclal distinction is to be found In the ochool oyotem" . . and with the Act of 1830, there arose a "snob-appeal" that only the above named schoola could "give an education fltting a boy for comand in busines, in politics, in the arwy, the civil service, even In the arts." Actually, the schools served the purpose of

1Dent, p. 19.

2D. W. Brogan, The Bnilleh People: Inpreselong and Observatione

(New York: Alfred A. Knopf, 1948), pp. 20-21. 
refining the chlidren-thelr habite, dress, and speech, for exsaple in order that they may rlse above their level ia acelety. Indeed, it is thla element of pomposty that Geoge Bernard show ridicules in Ermelion. Consequently theae areas exexted preseure in Paxliament for technical oubject mater in the public echools. James Bryce observed:

Latin 1s taught to every boy . . artthmetic and even mathemitics are looked upon as abjects of quite inferior tiportance; modern languages are Iitele attendad to; chemiatry--phyales-mare scarcely heard of. 1

St111 there were volces agalnst change, such an that expressed In an unolgnad article in the Engliahwoman'. Domentic Magasino of June, 1864. Openly challengtng the "combetoner. for Inquiring Into the atate of public schools" the author indicated hle praference for things as they were as he uxged his renders to:

Choose a chool primarlly and eseentidly cluseleal for ochools pretending to combine studies_woderg with auclent

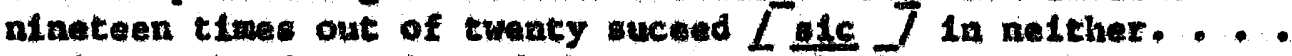
It Is on the formetion of character, higher atm than mare clasefical and sclentific acquirements that our Univereities and public echoole teke their stend. 2

Neverthalese, the myoplc viewe expreseed in this article, representative of the rural viewpolnt, were challenged by worldwide events such as the fact that Incoln signed Into Iaw a bil almed at education for the Industrial worker In America. Shortly thereafter, the Industrialized North defeated the agrarian south and on the continent, Prusela, with a highly developed technical educational syeten, triumphed over Austria. Thus, perceptive Bnglishman ascertalnad coxrelation between a nation' power and Ito

\footnotetext{
1H. A. C. F1 mer. Jumee Bryce (New York: The Macmillan Company, 1927). P. 106 .

2The Eng1Lh Woman's Domatlc Kagarine, vo1. 9, no. 50, June, 1864. "A Classtcal schoor and Coliege Education," po 77-81.
} 
educat1ona 1 matem.

Throughout the urban areat there was widespraed clamor for elementary education pald for by local taxes and undex local control. Indeed, an Bducation Ald Soclety was formed In Manchester and an Education Lague appeared In Birminghem; the oupporters of these groups favored free, compalaory, unsectarian education. Opposing groups that tavored the existing ayotem of denominational schools quickly made their viewpolnt known. Consequently, this constituency presaure forced Parliament to appoint a comentee to Investigate the atatus of elementary education In the Induatrial axass of LIvexpool, Manchestex, Leeds, and Birminghem. The direct reoult of thle investigation together with a concern for the recently enfranchised town workere as a result of the Reform Act of 1867 , was concerted ffort in Parliment by the Iiberals for govermant control of leatentary education.

In a spech before Commons in aupport of his Education BL11, Forster stated that "not more than two-fifthe of the wowking clases between the ages of six and ten [were on the 7 regleters of covernment schools, and only one thitd of those between the ages of six and ten." He pointed out that in Iiverpool,

estinations indicated, with 80,000 children between the ages of flve and chirteen, there ware 20,000 children tho attended no school and 20,000 wore in schools not worth the name. In Munchester, 16,000 children out of 65,000 were deotitute of achool accomodationo. I bellev we approach the subject [of primary education 7 with a due regard for its importance. We do tt to the hope of doing great good by removing that Ignorance which wo are all awere is pregnant with ezime and mleery and misfortunes to lndividuals and danger to the comanulty. The queation of popular education affects not only the Intellectual but the moral training of a vast proportion of the population and therefore we muat not forget that in 
trying to do grast good it is posatble to do harw. 1

Moreover, Porster called attention to the two fuctions by pointing out that there were "those engaged In the educatlonal affort" who preferred that their endeavors should not be unduly "Interfered with"; and there were those who "say there ought to be grant improvement" and this group "advocates ayutam wors or less now." Forster malntalned that there would be no compromalse by the Government since what was needed was "B11 to meet not only today's needs, but tomorrow's well."

Forster continued:

We have helped 700,000 but left unhelped one million. Hot leaving out unalded school-me shools which do not receive Government assistance are generally apeuking, the worst schools and those least fitted to give a good education to the children of the working clasees. . . . Good schools become bad ochools for the children who attend them for only two or thres days in the week or for only a few weeks of the year. And though we have done well in asaloting the banevolent gentlewan who have estabilshed schools, yet the result of the state leaving the Iniative to voluntary is that where the state help hes been most wanted, State help has been least given and that where 10 was desirable state power be felt it was not felt at all. In helping those only who help themelves, or who can get others to help then, we have left unhelped those who most need the holp. Notwlthstanding the large sum of money we have voted, we find a wast number of chlidren badly taught or utterly untaught and too my bad schools. - . Hence comes a demand from all parts of the country for a complete system of national education. 2

Forater offered a twomfold plan: to cover the country with good schools and then to get the parents to and their chi1dren to the schools. He cautloned that care should be taken In bullding up so that the old might be preserved rather than destroyed. "Our object," explatned Foroter, "18 to complete the present voluntaxy system, to f111 up gaps - . With the least possible expenditure of public money." 3

\footnotetext{
Langard. p. 443 .

2Ibid. 443-444.

3 Haneard. p. 444.
} 
With the otaunch ald of Prime Minister Gladstone, the Foratex B111 was succesefully maneuvered through parliamant. It wa political battle all the way; and the religlous controversy was paramount during the thirty nighte the Bi11 was debated " Party 14 nes vere oblitarated, for exmple, a member of Forster' on party vowed to see that For ter would be outed frow the Iberal Party for betrayal of the party' beic objective which had long been "to wret the education of the young out of the hands of the priests, to thatever denoninntion they $x$ ight belong." 1

Further, contrary to Forster's earliex scatemants, the 8111 of 1870 was a compromise, born of polftical expadiency. The Forster B111 contained three elewents: a dual systen, a conselence clause, and a fized ting-table for the teaching of religlon. undax the dunl syetem the voluntury schools belonging to the varlous denominutions vere glven recognition--howevex, In order to "I11 the gaps" supplementary "board" schools were to be set up by local authorittes, elacted for this purpose and given the wuthoxity to levy a contribution to the cost, a rate not to exceed threepence in the pound. Conaclence was anfegunded in a clause that preventad a child's attendance at a place of workhtp or a Sunday school or a religlous observane if his parents ox guardians objected. Thls clavee applied to any grant-alded achool (che denominational schools) as well as a board school. Moreovar, it was agreed that religlous instruction was to be offered at a prascribed the ethar at the beginning or at the close of the school day in ordar noc to interfere with student"s attendance at othex lescons. An Important feature of

1 Hanserd, March 3, 1870, Joseph Chamberlein. 
this compromise was contalned in an amendment known an the Cowpex-Temple

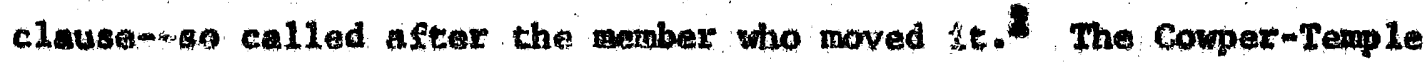
clause stpulated: "No religlous catech1am or religlous formulary, Which 1s distinctive of any particular denomination, shal1 be taught in the school.:2

Angry exchanges were mode betwean Prime Mulster Gladotone and the ulberal malcontent who maintained that the B111 was being "forcad upon the country ageinst the declared wishes and earnest ramoatrances of the entixe Ilonconformlat body," body, it was pointed out "Which formed one-half of the nation and more then one-half of the Liberal Party. 3

After conslderable wodtfication, the Forster B111 bacame 1av a the Rlentary Act, 1870. H1th Its pasage, "the first foundations for a universal gystem of aducation were latd. . education vas no longer a charity but a right.:4

Although the intent of the B111 as Forster had Indicated wes that board achools vere not to supplant the voluntary schools, many regarded the board chools as the hope of the future.

The school boards had aythority to borrow money on the security of local taxras Lele 7 in ordex to purchage ballding sites and erect schools. Moraover, the boards had the power to levy caxes to met ouch part of current school expenses that were not covered by the Coverninent grant. Although the voluntary schools were to recelve funds from the Covermbent grant on the sase basts as the board echools, the voluntary schoola were dented any share of local

1. O. Lester Smith, gducation In Creat BrLtain, London: Oxford Untvare 1ty Press, 1958), pp. 73-74.

2yensard, March, 1870.

3 rrank sinth, p. 289 .

${ }^{4}$ Brian 51mon, Studies In the Hetory of Education: $1780-1870$

(London: Lawrence and Wlohart, 1960), p. 365 . 
taxes. Th1 left the voluntary schools to meet their exceselve expenses by means of endowments and subscriptions, since both board schools and voluntary schools charged fees.1

Churchmen gave monetary support to the voluntary schools and by 1880 , the Church of England had added a million places. The board schools, however, because of more etable finances, made phenomenal gaine. Further, the disparity between the two systems was exphnalaed in their locations: the board schools ware mainly city schools and the voluntery schools were more munerous in the rural areas. The dual oystem was extrevagant and the factional1om was further antagoniaed by the clergy's resentmant of the extension of clvil control into a province that had been for so long exclualvely its own.

Indeed, the board schools soon were making Incursions into the realm of becondary education because of popular damands. In general, secondary educetion was only avallable to the atudente whose parents could afford to pay the fees at public (by American definition--private). endowed, or private schoolo run for profit. These latter schools were frequently of Inferior quality with very poor educational standards.

A Royal Combleton under the chairmanghlp of Lord Taunton was oet up to report on all schools in thigland and Wales. Of concern were the adequacy of provialons for becondary education and the education of gixls, the comparative value of private and public schools, the 1deal size of schools, the use and abuse of educational endoments, curricula, teaching effictency, material equipment, the training of teachers, the feempying as opposed to the free system, and the geographical distribum tion of schools, whether endowed, proprletary, or private.

1Annual Reporte of the Department of the Interlor: 1902. Report of the Commiseloner of Education the year 1902, Vol. I. Washington Covernment Printing Office, 1903, p. 1014. 
The private schools were generally pronounced to be deplorable.

The combittee reported that

Axithnetic, penmanship, posalbly also Irench are assiduously cultivated: Latin 1o languid: even mathewatica is pushed on one ide. Not in more than three or four private schools In the whole country did I find that the rain object of teaching was to invigorate the alnd by these robust otudies. 1

A nembar of the Taunton Comiseion, Jemes Bryce urged that any scheme of educational reform mut be comprehensive, that it must regard boys' schools and gtrls' schools, elementary, secondary, night and day schools, technical ochools and unlversities--all as a single plan. Bryce contended:

Instruction in England is at the present wholly unorgenized. Endored schools, proprietary schoola, State-paid primary schools (nationil and British) 1le ocattered here and there where chance hes placed them each managed without reference to those of different class and grade. Some netohbourhoods axe overgtocked with schools: others equally or more prosperous have no schools at all ar none of the grade needed. The whole thing 18 a chros and the first atep to aducational reform is to recognise the necessity of having all places of instruction organised upon some genaral and defintte principles so as to form parts of an ordered and comprehensive whole. 2

Inovitably, the dual eystem brought about consideratlons of superlority and the prlority of right, thus in the last decade of the century, the cross Combision was appointed to evaluate the progress of elementary education. Because there was ouch divided ilfference anong the combsion members, a jorlty and minority report resulted. While the majority favored the voluntery aystem, the minority was critical and Impatient to complete a unifiad national syatem.

1H. A. 2. Fisher, Jamee Bryce (Bev York: The Macmillan Company, 1927). p. 107.

2Ibld., p. 111. 
The majority clained for voluntary effort a right to supply effictenctes equal to that of the School Boards, and asaerted that the voluntary schools ware better managed than the board achoo10. - . The minority clelwed the prior rights of the School Boards to supply deflclenctes and also the ouperforlty of the boaxd chools--tin bullding . . were better, the ataffing was more liberal, the examination result ware auperior, and the curriculum was more extenelve. They The comolsaton ralnor 1ty 7 complained that in the suill areas where only one shool existad lt was usually voluntary whool, and thought that undenominational schools ought to be within the reach of the whole population. To the clalm that a consclence cleuse protected parents in a ingle school area they rmplied that a consclence clause, though rarely violated, was "wholly lneffective," and tte protection wae "111usory." -. - every parent should have tho power to send hic chlld to an undenoulnational school.1

The comlasion recomended that the school-leaving age be ratead to fourteen and that evening schools should no longer be regarded as elewentary schools, but should give Instruction in oclenee, art, and technology and offer opportunities for recreation and social 11 fe. Pexhape the most importint recomendation by the Cross report was the need for coacher-training fecllities and the approval of the creation of dey trainting collages in connection with the untversities. . . i2 As the aineteenth century drew to a close, resistance to state intarvention remelned formldable. This force compounded with the aglioh characteristic of preferring to met oach new problex as it occurs rather than atteupt to make future projection as ans for carefully planned systews resulted in a situation that found educaslonal admialotration 1 a statio of "administrative mudile." 3 In 1894 tha

1 Frenk sulth, p. 325.

2Ib1d.

33. Adamson. Endiah Education: 1789-1902 (London: Cabriage University 2ress, 1930 ), p. 156. 
Bryce Conmilssion was established to investigate secondary education.

The Bryce report wes axtlculate and to the point:

There is one feature in this growing concern of the stete with education which must not be overlooked. The growth has not been elther continuous or coherent, 1.e. It does not repreaent a extes of logical or even connocted sequences. Buch one of the agenclas. - Was called into botng, not merely Independently of the othere, but with little or no regard to their existence. Bach has renalned in its working loolated and unconnected with the rest. The problems which secondary education preaente have been approached from different eldes, at different times, and wth different vlews and (gins. . . It is not marely in the intereste of mater Lal prooperity and intellectual activity of the nation, but no lass in that of Its happiness and moral strength that the extension and reorgantation of Secondery Bducation seem entitled to a place among the first subjects whth which sound Ieglelation ought to denl. 1

At the time, there wexe five central authorities concerned in one way or another with the whools. The Bryce Comalsion found that no accurate definition of elementary, secondary, or cechntcal education existed. Indead, witness callad to testify before the Conolssion admitted that he was unable to draw the IIne where elementary education anded and secondary education began. Further, technical education was viewed as sonething quite different from secondary education. ${ }^{2}$

In 1896, Lord Sallabury' Covernment ettempted to alter the adminlatrativa structure of the educational aystem in a B11 prepared by SIr John Gorst. The B1II advanced a step faxther than the proposals advocated by the Bryce Comales Lon Inesmuch as the function of the school boards to be abeorbed within the authorative structure of the county

IFtahex, p. 299.

Ibld. 
boroughs with all types ochools brought withln thls framework of local control; Included was fianclal assietance for the voluntaxy schools. Naturally the 3111 was strongly opposed by school board representstives and the Nonconformists who took issue with the extension of rate ald to voluntary schools. The B111 was dropped and the 3alisbury Governwent turned to the work of creating a c3ntral authority fur education. With the passage of the Board of Education Act in 1899, th1 was accomplithed. The Act created a central authority to superintend matters relating to education in sngland and Wales" and authoriged the now Board co Inepect secondary schools.

Behind these two Bills was the driving force of Joseph Chamberlain, a forwer member of the Liberal party, who at wayor of Biruinghum had accosufully reorgenigeu that clty' Lacal ageneles into an offlcient adointetretive structure of auntelpal sarvices. Chamerlain was Imbued wth the destre to accomplini for Bagland what be had effectad in Birmingham. He was meaber of the Fablan Soclety and is repressntative of that amalng group of aidd le class bourgeosfe intellectuals whose Impact is discornible on the topese of the power struggle between the church and tate ovec the educational syotem of Englaud, coaplicated, according to the bietorian George Macnulay Tevelyan

Iby_7 the revival and sxentheming of the old two-party systep, The peculierly Bnglith tradition of the two perennlal parties had been to sowe exicent xeplaced by a group ayatem of politics during the unchallanged rory predominance with which tine / ilineteentin / Cuutury openad. But at the tive of the Reform $\mathrm{B} 111$ of 1830-32, the whigs furbished up thetr old traditions with new war-crlos ans programes, and both partiee thenceforth noved forward, forming as they went a kulaidescople uceasion at new social alliances in the ragidly changling world. 
The undexlying principle connecting the Liberals and the Conervatives of Victoria's reign in an actunlly traceable succeseton with the Whige and Tor Les of Charles II, was the continuous antagonten of Church and Disseat. That lasting dualien of Englieh religlous 1ife was bound to reflect itself In a political dualiom, so long as certain monopolies of the Church were intalned. For two hundred years it gave reality to the otherwive artificial parmenence of the tradition of the two partia frcm one changing pertod to anothex. The workingclase wovement at the beginning of the kineteanth Century wa in part connected with Dissent and we at times alwost altogether outalde the Influence of the esteblithed Church. The denominational apecte of polltice therefore served to connect the - : working clase to we extent with the Whig-Iiberal Party . . . I

Fron the beginning, the Fablan Society exerted pressure on the status of education In Bnglend.

H. M. Trevelyan, Hetory of Englund, Vol. 3 (Garden City, Now York: Doubleday and Company, 1956), PD. 152-3. 
Pant Two: Mabteniom and Hationalisation 
PART II

The Fabien society was founded in London in 1883 and was composed of a growp of men and women tho sat out to "apread practical viewe on Inenediate and preselus social problems and to indicate the way for theix embodiment in legtelative or admintetrative meatures."I "Rermention" wae the term adopted by the Fablen for their progran of presure politLeking.

The leaderohip of the Fablans, whose total membermhip never numbered more than a few thouband, conalsted of sone of the "wleest, most learned and witleat men and women of that exa."2 George Bernard Shaw, H. G. Whlle, Sydney OLIvier, Annte Besant, Rdvaxd Rease, sldney Webb, and Beatrice Potter were examples of the Intellectuals who joined the

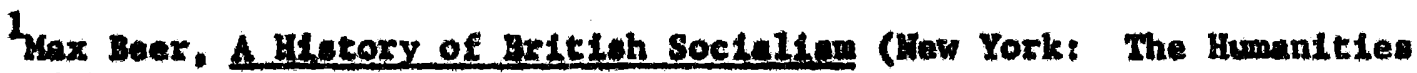
Press, 1919), p. 277 .

2A. M. Mc Briar, Labian Soctellam and En 11sh Polittce 1884-1818 (Cambrtdge: The Untvaralty Prats, 1962), p. 349. 
Fabians.

The creative talents of Shaw and Wells, unknown when they atarted working with the Fablens, were utilized, as were the gifts of Beatxice Potter and S1dney Webb. Bentrice, for exmmle, was an expert soclal researcher whose real passion lay in "the collection and discovery of facts about history, the nature of society, and social organizations and theix gradunl asemblages into a satiefylng pattern."1 S1dney Wobb, wae "oharp as a London aparrow, and mentally, as owntwo rous," 2 and he read rapidly and had a prodigtous, photographic memory with the ablitty to grasp in an Inotant the central idea In any document he read. Further, Webb had an uncanny ab1lity for drafting accurate resolutlons, amandwent, or reports, very quickly. As a rablan, Hebb proved to be asectoue propagendiet in converting statistics for populer consumptLon. In 1892 sidney and Beatrice were marr 1ed. From the beginning, their marxiage, according to Shaw, wa "a perfect colleberation."

The rablans ade it a policy not to take any action without a thorough study of the facte. The general propaganda of the Fablans, addreseed to the public at Inrge, was in the form of tracts, Inexpenatve, Informative and easly underatood factunl Information in booklets meldom more than twenty pages Iong, lectures, debates, and discuestons. Durtns the "Pablan heyday. . they were able to wirepull both ides of the House of Commone."3 Worklas through the back door of Parliament, the

Margarat cole, The story of Reblen Soclellum (Iondon: Mercury Booke, 1961), P. 81.

${ }^{2}$ A. G. Gardiner, Portralt and Rortente (New York: Harper Brothere, 1926), p. 255 .

3Ane Iremantle. This Lttle Bani of Prophets: The British Deblans (New York; The New American Library, 1960), P. 53. 
Fabian leaders cheerfully accepted the role of unofficial public gervant that was thrust on them by the ovarburdeaed and hurried parliamentarians Who had netther the time nox the know-how for research of the new soctal problems that wera deranding changes. Behind the scenes of government, the Fablans worked to educate the Minietere and parwente the lawmakins process.

One of the most Important 1iterary efforts of the Fablane was the publication, In 1889, of a serter of thalr lectures, edited by shaw, entitled Iablen Reesy. The book nold for ofx ohillings and the first thoueand coples went in leas than a wonth. One of the essays, written by stdrey Webb, contulned the folleving etatement:

Tree elementary and public technteal education is now prectically accepted on both otles of the Hoube, prowlded that the so-called "voluntary achool,' thenselves haltmalntelnad from public funde, are not distigutuhed.I

Following this "essay" we an outline of rabian "demands for further loginlation" with the notation that the outline had appeared in the nowepaper, Stex. Ausuat 8, 1888. The oubject, "Bducetional Reform," was out11ned as follewe:

Qbiact:

To enible all, even the poorest, chlidzen to obtain not marely one, but the best education they are capable of.

Mans:

1. The truadiate abolition of fees in public elenentary schoole, Board or voluntary, with a correnponding increase In Government grant.

2. Creation of a Minieter for Educution, with control over the whele aducational syutem, from the alementary co the unfverofty, and ever all educatlonal andowments.

1George Baxnard Shaw et a1., Rebien Euave (6th sd., 1962;

London: George Allen Onwin Ltd., 1889), . 85. 
3. Provistong of public technical and becondary schools whereever needed, and the creation of abundant public secondary education at evening schools.

4. Regiatration and inspection of 11 private educational establighnenta. 1

Cartainly, the reform of the educational syotem was a parawount concern of the Fabian soclety, In fact this concern for education "provides... the root classical example of 'Bablan." "permeative' tactics in successful operation."2 According to a Babian historian, "The aducational scheme of the soelety wa not, howevex, the jolnt production of It: experts. It wae entiraly the work of sidnay Wobb, 3

Webb ceme from working-clase fomily, from whlch "he eaxly escaped through scholarshipe."4 The principal source of his family's Income had been a hairdressing shop operated by his mothex.

It was the tho, after consulting with a friendly customer,

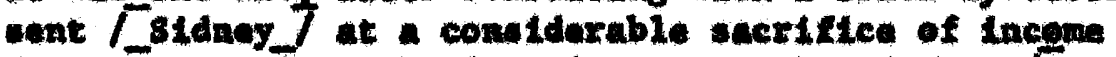
firet to suiss achool to learg French and then Fo live with Germin fondly in Wiemer 7 to learn German-an accoupliohmant hich Indirectly led to sfdney getting into the flute divieton of the Clvil serviee."

S1dney Wabb, after tea years in the Colonidi offlce, where he returned as Miniter, Later, we elected In 1892 to the Londen County Counc11.6 Hexe he arved for elghteen yeure during whlch tine the L. C. C. developed

libed., p. 87.

2yargaret Cole, The Story of the Fablan Soctalles, p. 102.

3tdvard R. Pease, The Hintery of the rablen soctety (1st ad. 1918; New Yorkt Marnee \& Hoble, Inc., 1963), p. 142 .

4rementle, p. 43.

5 Baxbara Drake and Murgeret Cole ads., Our Rartnexshle Bz Bentrtce Webb (London: Longman, Green and Co., 1948), p. 3.

6. H. Tawnoy, The Wabbe and Their Work (London: Tablan Publicationo Limited, n.d. Erom lecture delivered kay 11, 1945), p. 7. 
Into one of the "greetest educatlonal authoritins in the world. . ." A serles of accldents started the $I . C$. C. on Its career at the education euthoxity. The Conservative goverment had introduced, in 1889, b111 to provide for technical education, giving the power of levylng the rate and of providing the technical education to the County Counells. The Iondon School Board had protested, malntalning that it should have the rating power; howevar, G. I. Goschen, who took Germany for his model, forced the b111 through Parlianent, and it beceme the rechnteal Inutruction Act. The following year, a centlict arose between the covernment and the Temperance movemant over the question of "whilkey monoy"; A. H. C. Aclend, an "enthusiast for public aducation" fought for three days to obteln thi allotwent for technical education. To this the Government agread, thus the power and the funds for technteal education had been glven to the L. C. C. Nothing done with the "thtekey funds" unt11 shortly after Wabb's alection to the Counc11.1 Wabb's first motion called for the appointment of a comattee to axemine the need of techntcal edveatlen and the way in which the Counct1 might bet make use of Ite poware.

This reaulted in the creation of the Technienl Bduchtion Comaltee and SLdney Wabb wes nomed cha1rman. Imodietely, Webb hired H. Llewallyn

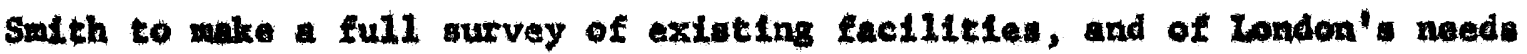
for education bove the primary leval. Next, with the ald of Aclend, Webb obtafned the broadeot posslble Interpratation of "technical education" 
unt11, In hte on woxds, it lueluded "she tenchlng of every conceivable

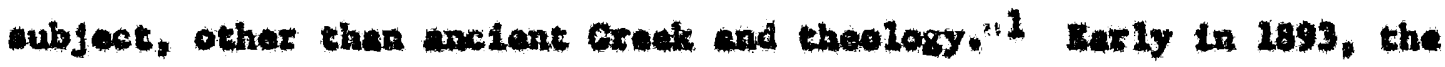

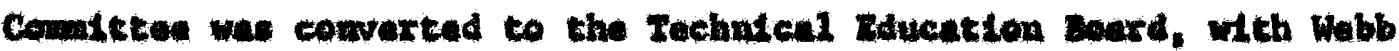
cont Iouting as chatrmen:

When Llowelly socth reported In 1092, thore wee an elementery roll of 690,000 paplis, yot the total muber of scholerehtpe

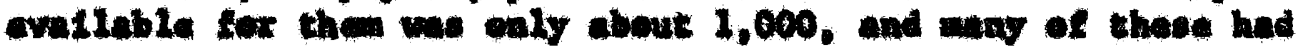

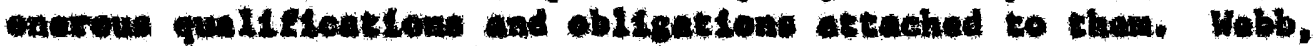

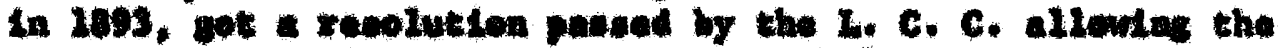

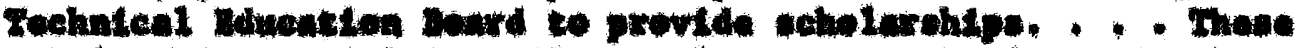

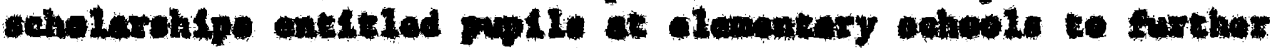

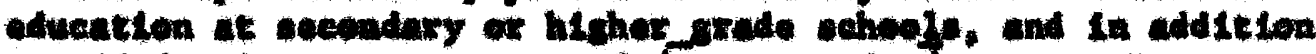

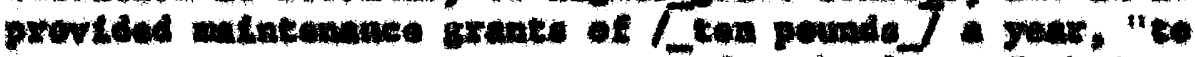

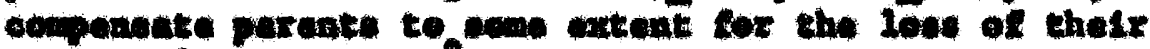

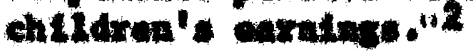

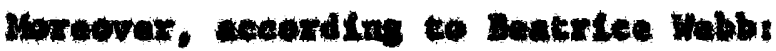

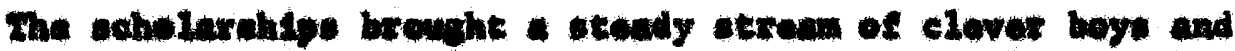

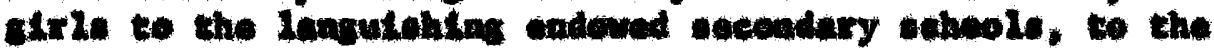

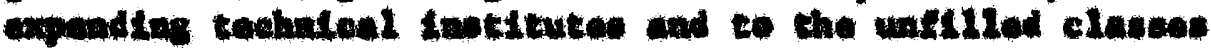

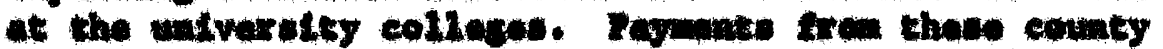

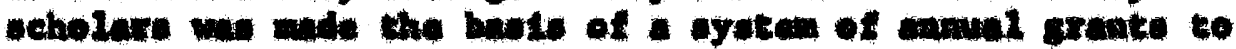

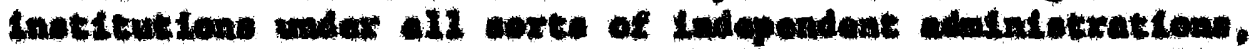

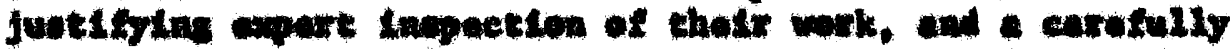

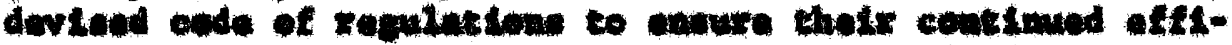

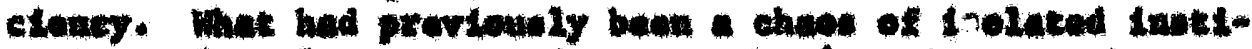

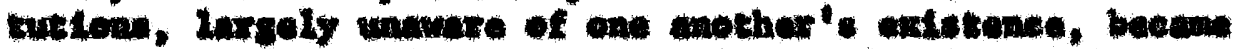

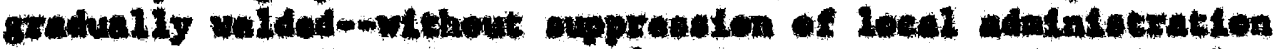

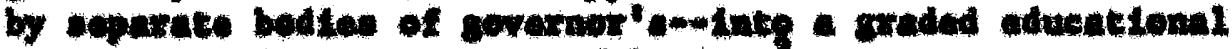
syotem cowerting overy part of tondon. 3

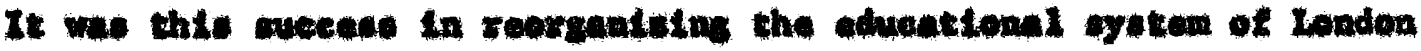

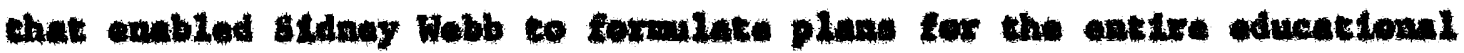
oyotem of smeland.

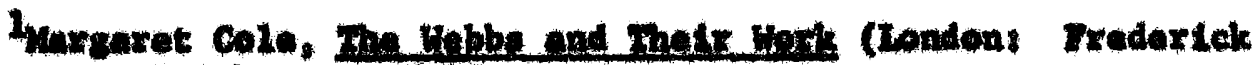
mu11er, utd., 1949), pp* 8780.

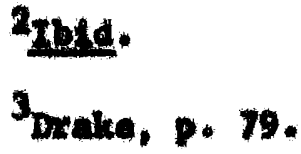


In the waw year the Techical Rducation Board wa Inotituted. Iablan Iract Iventy-five. "Question for School Bourd Candidates," was Iseued. Irect Ivanty-6lve wa ectunlly a liot of quastens, set out in celuma form over lour pagan, with blank opaceo providad tor

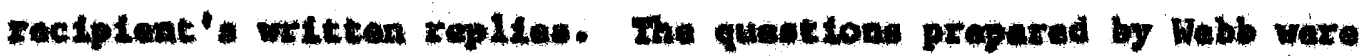

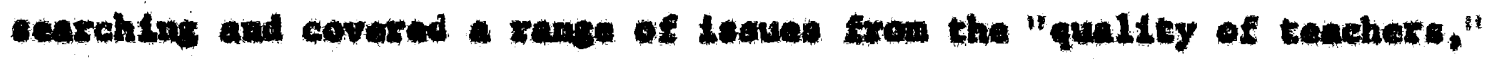

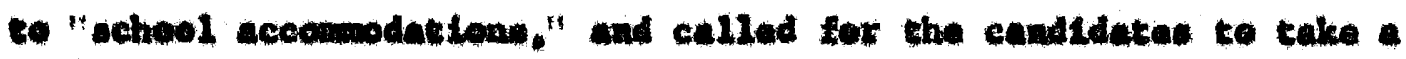

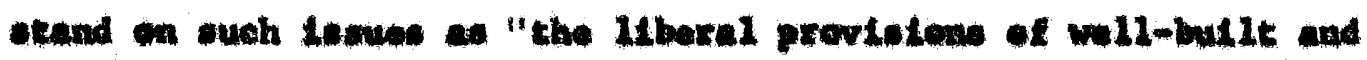

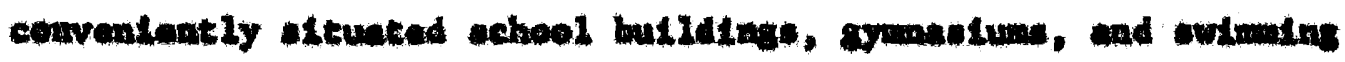
bathe," as wall as an optaten on the "rotorm of Inw in order to bring

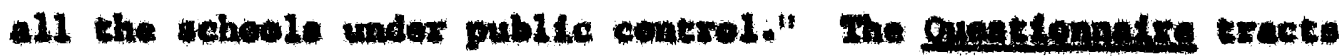

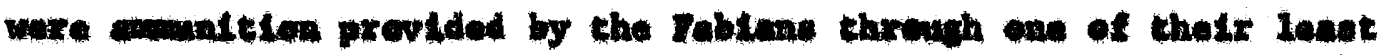

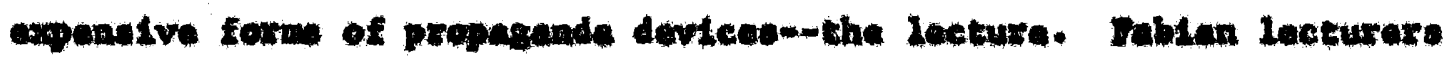

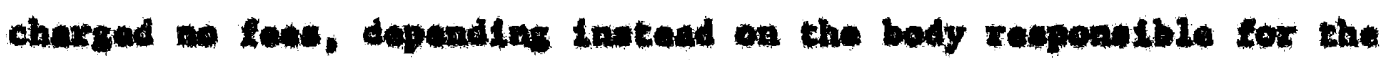

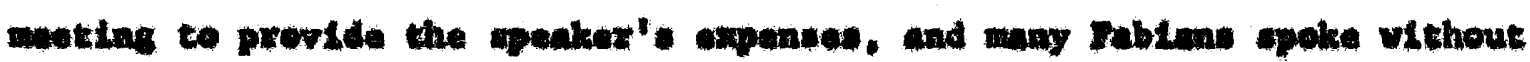

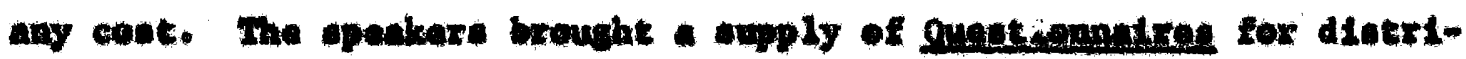

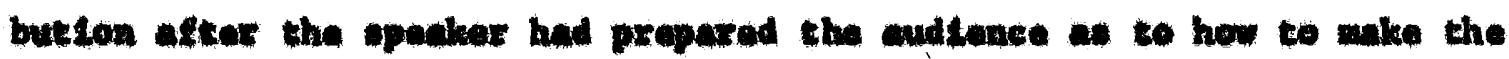
bete we of the muterlal. Atthough the questonnatres ware dentgned

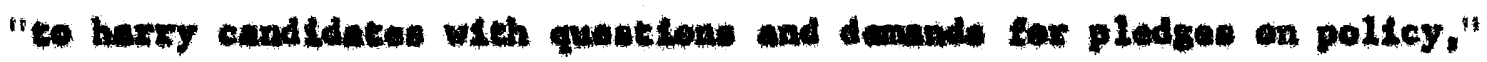

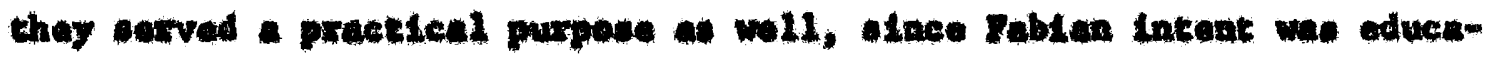

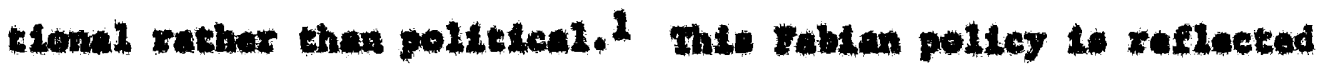


In a statement made by Edward R. Feded," ". greet woelel changeo can only com by consent. 1

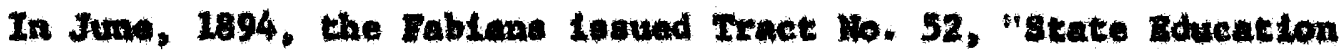

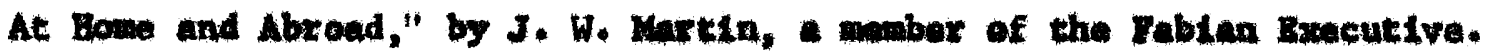
The earlier tracte had bean leoued unetgned, however, the Fobtane had

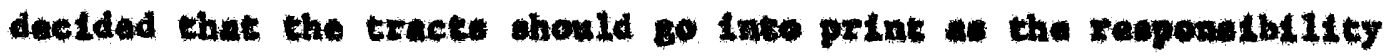
of the author, huvins only gonoral sectety aprovel as Infermutend.

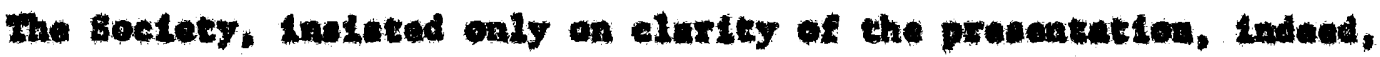

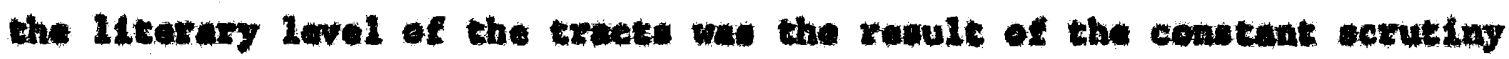

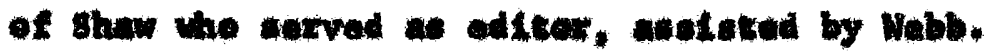

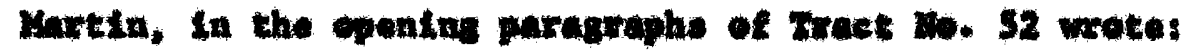

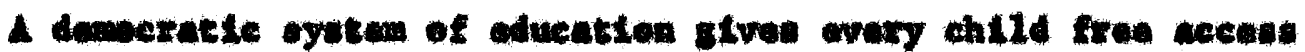

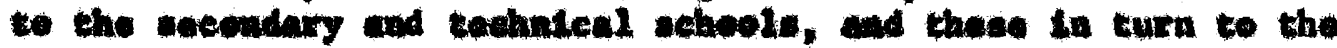

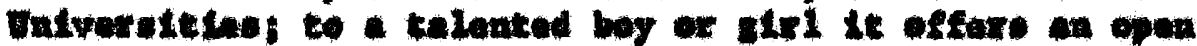

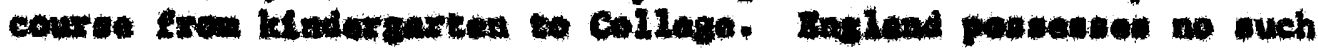

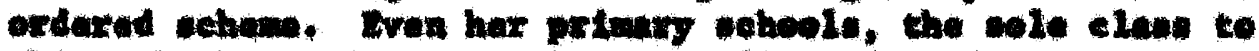

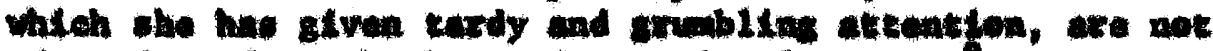

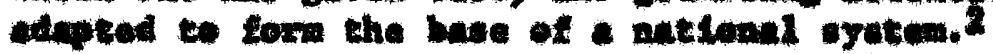

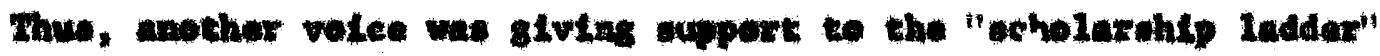

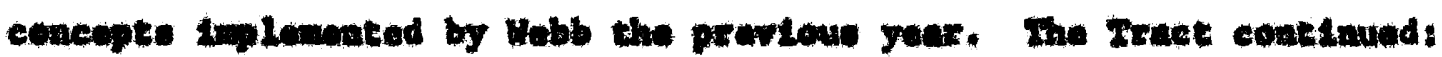

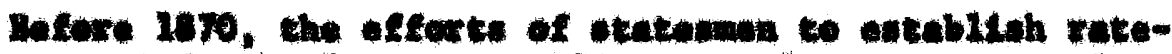

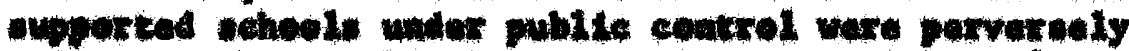

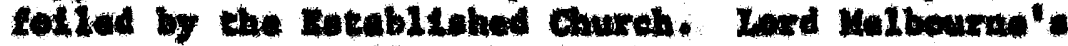

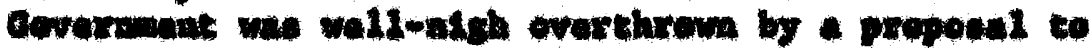

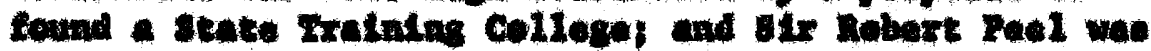

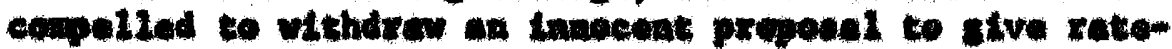

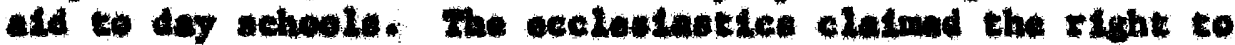

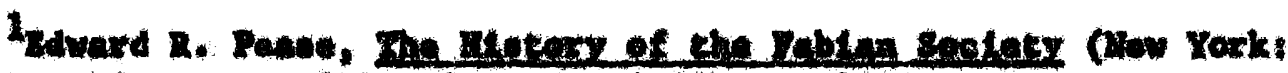

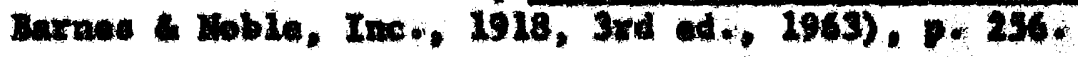

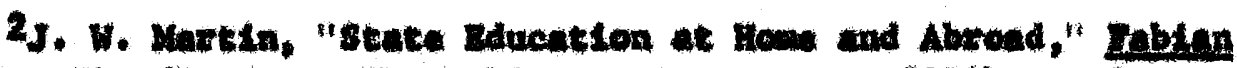

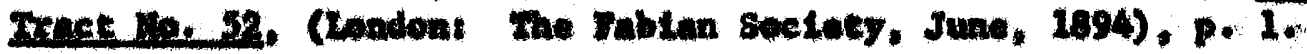


11cense all teachers under some musty old canon, and tho

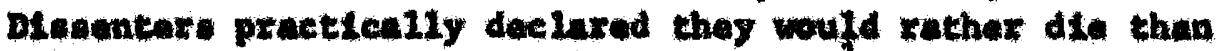
allow the Church any axtenston of powex, 1

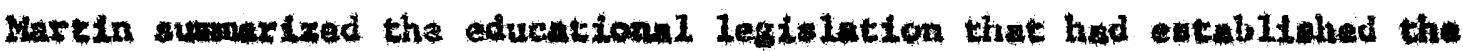

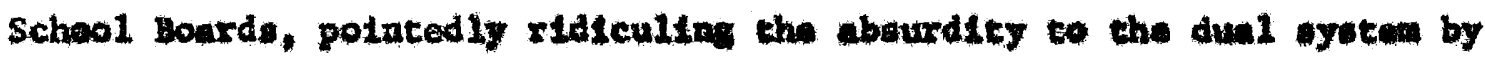
atuting that no country abrend would entruat ite "state vehools to privata mungemat." Maxtin further blested the condition of the ochool

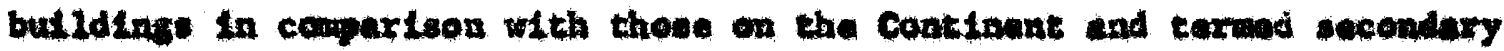

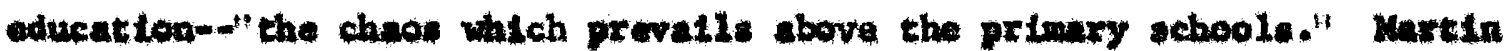
concluded:

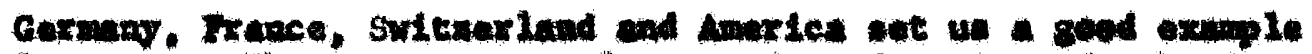

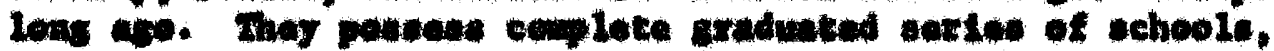

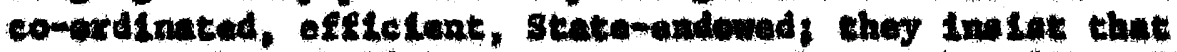

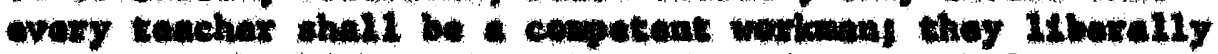
mevuruge the blghese brancher of study! tway halp the poor

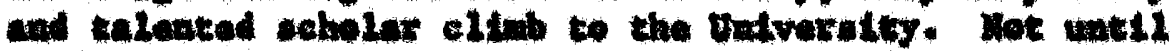

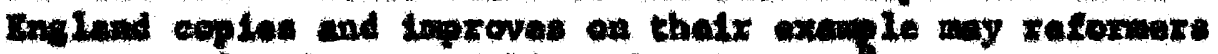
conse complatatus, of valuan be at reot.?

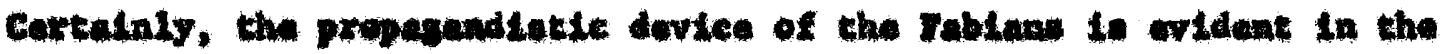

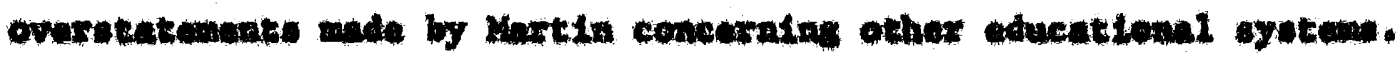

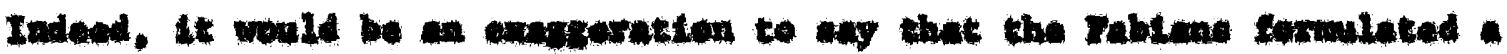

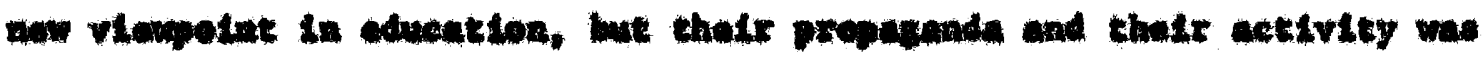

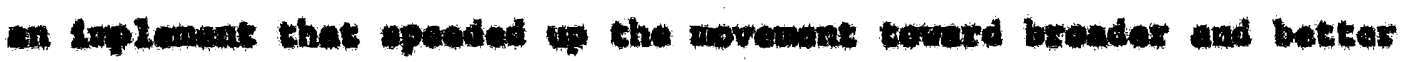

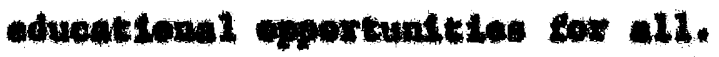

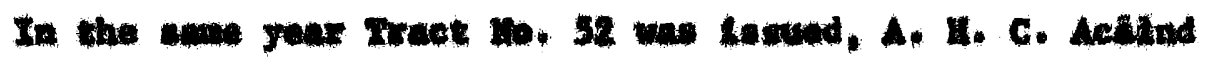

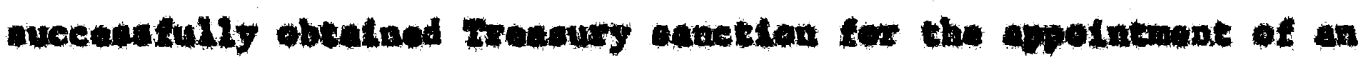

Irute., p. 2.

2zuce. P. A. 
officlal whose duty it would be to keep the Goverment Informed about educational developments abroad. Consequent1y, In 1895, the office of Special Inquiries and Reports was established, with Michael E. Sadler appoInted Director. Robert Morant, recently returned frow Siam where he had served a tutor for the royal famlly since 1886, during which twan he had also assisted in the reorgentzation of the SIanese school aystem, answered an advertisement for a postion under Sadlex and was h1red. Morant's research for Sadler of the French and SwLe educational systems was a fuctor that enabled Morant to grasp the ignificance of the chaotic adminletrative stuation In Bnglend's educational system.

Thus, In 1896, whan the Sallsbuxy Covernment attempted to alter the adminletrative etructure of the aducational aystea, ther is no doubt that Horant was aseleting behind the scenes in research capactey. At the same time, Sir John Coret, Wichael Sadlar, and Llewellyn Saith were in contact with Stdney Webb. As noted in Beatrice Wabb' diary:

Whicurn, 1896.--Sidney much enjoyed colloquy with S1r John Coret (acting Minieter for Iducution). Mcheal Sadler, Hewellyn Suith and others about Bducation Bill: that in, replacing ad hoc bodles by one set of representetives chosen to manage all the busines of the locality (but doubtful whether the B111, as It stande, w111 effect this); aloo, not agalast helping voluntary or denominationul choolo in return for a masure of control. which is bound to grow other cluuees, enmbling public authoritien to absidide private venture schoole, he looke upon as radically. He, however, recognises that it 1. no good for him to oppose the Bll--far betcer to appreclate the good in it and, by appreclating 1t, get some Influence in amonding it in our direction. And he is fortungtely placed for this purpose... friendly acquatntance of Coret's--ae a frlend of Llevellyn smith and Sadler, and acqualnted with all the educationaliats In London, he 10 able 
to be constantly suggesting amendments which are favourably constdered by those in authority. 1

Although thie Education B111 was withorawn, the diary notation suggesta the type of Fabian "permantion" carried on by the Webbe while they entertained some of the leading politiclens in their home.

At a Fabian weeting In May, 1899, proposed tract, "The Education Muddle and the Way Out" was the subject of discuselon. S1dney Webb introduced th: aixteen resolutions; ix on ${ }^{\text {general }}$ Rrincip1es," advocatine the trans far of education to the local government authority and the abolition of School Boards, ware adopted.2 Several amendments were defeated and the group became divided in their views, enpecially when it was revealed that Webb and Morant had devioed a whene In whlch state-ald to church ochools was to be used as "the balt to persuade the Conmervative government to pase a suttable Act."3 The neting was adfourned unt1I Hovember and at that time a Revision Comittee was appolated to work out the differences. Thirteen months Later the tract was resubmitted and in January, 1901, Fablen Tract No. 106, "The Education Mudd1e and the Way Out," was published. Tract Ho. 106 was "a constructive criticlen of Englioh educationel machinery" and opened with the statement, "Our educational machinery In Bngland has got Into a notable mess." There vere two sectlons: The Local Authorities and The Central Authority. Under

\footnotetext{
1Drake, Pp. 132-3.

2pease, p. 143.

3cBriar, p. 213.
} 
"The Local Authorities," "The Present Muddle" was described. The

School Boards were to be abollahed in all but the largest towns. The

Tract concluded that;

The democratic Ideal in education 16 not merely that a ladder ohould be provided, whereby a fav otudente my climb unimpeded from elewantary school to the university; though even this ideil has 1ittle chance of realiation so lons as ocme runge of the ledder are under no one's care, and competing gundians squabble for the rlght to look after others. What the national wellbeing demands and what we must instet upon is that every chtld, dull or clever, rtch or poor, hould recetve 11 the education requilette for the full development of 1te facultles. For every ch1ld, in every part of the country, at least a national minimum of aducetion mute be compuleorily provlded. Above and beyond that minimum we must see that apple provioton la made for varying facultes and divergent tantes. Our plan is to extend popular control and popular aselstance to every branch of educetion; to combine all the scattered and over lapping athoritles; and to Iink together the muntclpal I1fe of our local authoritles with the intellectual life of the schoole by the concentration of all local services under one local body. Thi plen, it lo true, requires the ourrender of owe cheriahed 11lustons, and Involves scere delicate adjustmants to aut transitory formg of organization, but if these difficulties are faced and mot on the 11nes uketched out in this Tract, we shall bring the school into intimate connection ith the everyday 11fe of the country and eecure wo far as offlcial machinexy is concerned a ound and offletent aducational syaten.

The ot111 more important and more difficult probleme of what to teach and how to educete, remain for separate conolderation. 1

Thus the rablan indicated their emphasts was to be on the unification of the educational aystem In England, at this tiwe, but the door was left open to deal with the problem of teacher training and qualifications and oub ject-mateer.

1Lablan Trect Ho. 106, "The Bducation Mudd le and the Way Out," (London: The Tablan Soclety, January, 1901), p. 18 . 
The Cockerton appeal judgment in hay, 1901, made it Imperative thet a solution be found for the School Board problem. Friction was Increasing between the London School Board and the London Technical Bducation Comittee, of which sidney Webb was chairman. As a reoult of Governuent action, secondary education was being developed by the Cunty Counc1ls and County Boroughe under the Technical Inotruct 1on Act and at the sam time by the School boarda under the Ilementary Bducation Acte. Korant, In his remaurch for sadler, dlscovered that the action of the School Boarde was 11 legel according to the laws as written; this Worant brought to the ettention of Dx. Carnett. Sidney Webb was often aployed to radreft reporte for Garnatt who vas defending the County Counc11s.2 Upon recelving Morant' report, Garnete immediately challenged the legality of the London School Board's action in the extension of education withln the secondary educational framowork. Action wae taken by the Government Auditor, I. B. Cockerton, who levied a aurcharge on the scheol Boardy, with the result that the dispute was brought to the quean's Bench DLviulon of the Bigh Court and then to the Court of Appeale; Cockerton was uphald in both instances. As a resule, Parliament passed a sop-gep act that lagallzed the action of the School Boards unt11 a more approprlate measure could be enected.2

The cockerton deciolon, thu forced the lasue concerning the dual

1 prake, p. 244 .

2R. C. K. Eneor, Bngland: 1870-1914 (Oxtord: At the clarendon Press, 1936, 1949), pp. 355-356. 
educational systen and Sir John Gorat, Vice President of the Bducation Department, had Worant traneferred to his ataff with the aselgned tesk of drafting an Rducation B111.

In har diary Beatrice Webb comented,

Who would trust the bullding of a bridge to an who started with ouch an Infiniteatmal knowledge of englanering as Balfour or Goret have of nat lonal aducation and Ite mehtnexy? There seeme to be a settled conviction that any clever man, trained to any profesetion whatsoever, w11 aucceed in politics whether or no he knowe anything about the detallo of public admintetration. . . That lmpression we must try to dentroy. 1

Certainly, SIdney Webb viewed Ieglalation "as much a distinct eraft as shoewaking." 2 Turther, sidney Webb had supplied coret with advanced proofo of Irect $\mathrm{Ha}$. 106 late in 1900, whereupon Goret had requasted and was upplied "flfty coples of the galleyw to be pondered over by hie permenent offlctale." Horeover, although "The Education Muddle and the Way Out" was an anonymoul Tract, S1dney Webb was lte author. ${ }^{3}$ According to I. R. Peace,

How far the draughemen of the B111 were Influenced by the rabian ocheme cannot . . be estimated, but the authoritles at Whitehall were... anxious to see it - . and the trect when published wes greedily devoured by parplexed H. P. 1.4

${ }^{1}$ Drake, PP. 133-134.

2McBe1nr, p. 76 .

3yargaret Cole, Beatrlce Webb (London: Longmins, Grean and Co., 1946). p. 81 .

4panse, p. 144. 
In Parl1aikent on Maxch 24, 1902, A. J. Balfour mornd to bring In a 3111 to make further proviotons for education in England and Wales. Briefly sketching in the historical background of education, Balfour proceded to set the stage for the B11 by drawing attantion to the rivalries between the various group responstble for education and prompty pioposed as aolution the escublishment of a alngle authority. 1

Balfour" presentation followed the general outine as contained in Pablen Tract Ho. 106.

Under Item I. Sidney Vebb had witten:

There ara, In Bngland today, two distinct sets of locul eduentional author It1es, acting in the same arews, and aharlag the proviaton of schools between them. These are (1) the School Boards, (2) the Covaty. Borough and Urban District Councils.

The School boards. . . have inlindted pewere of ruttng, but are, In other respecte, marrowly restructed in their scope. Thay can maintain only "elementexy" wchools, as defined by the Acte and by the Day and Ivening "Codes" annuvily lasued by the Educatien Departmat. Wut they do not malutain ox centrol oven all the elewentary chools. More than half the childxen in e lemantery day achools . . . Are in the no-called "voluntary"i or denoninatlonal schools. . .

Thene two dietiact sete of local authortties ceme everputhere into more or less acute rivelry and conflice. 2

Balfour In hit presantation obsarved:

that wad dealing with education, secondary and primary, two lacted athor 1tles, the County and Dorough Counc11s on the one ide, and In certaln cases the School Boardo on the othar. Between these wuthorlties there was

Ihe Annual Regleter: 1902 (Londen: Lonponan, Graen and Co., 1903), pp. 99-100. (Moted hereafter the A. A.).

${ }^{2}$ Eablan Trect to. 106, pp, 3-5. 
necesarily rivalry; and bealde them were the independent endowed shools and the voluntary schoole whtch were not organised or brought into connection with primary or eecondary educational authorities, 1

In Irect Yo. 106, Webb next had proposed as alution,

There ought to be, in adch district of conventent alge, one public aducational authority, and one only; respon1ble for centrolling all the aducation malntalned in the disterlet out of public funds. . . It 18 . . O clear that large towa must be kept as diatinct educational units. Blraingham, and Manchestar, Liverpool and Leeds, can natther be broken up nor mexged. ". Leaving out of cccount London and the County Baroughe, we propose that, In the 50 Adataletrative Countie which wake up the rest of England, the Ceunty Councll should be ude reaponatble for thr provition and alntenance of every grade of education within tte area. 2

Webb suggeated that the Board of Lducation be granted by Parliament as the over-a11 authoritative agency of contro1.3

Dulfeur": Paxllamantary presentetion continued:

The euthortty under the Bd11 would be the County Counct10 in the count Ies and tha Borough Counctio In county boroughs. . . It wes not proposed to deprive any borough with population over 10,000, or any urban diatrict with a population of ovar 20,000, of thit jurladict10n. . . They would work through comalttee. . . which would have to be approved by the Bducation Department. 4

IThe A. R., p. 99-100.

Zeblen Trect Ho. 106, p. 11.

${ }^{3}$ The Board of Bducation Act of 1899 hed subatituted the Board of Education for the Bducution Department, the Department of science and Art, the Charity Comilentonars and th- Board of Agrlculture but had not ade any arrangenents for the orgenisation of this aew Departenent.

4he A. R., P. 100 . 
Ho fut the voluntary schoois, according to Iraet do. 106,

It is politicaliy lupossibio to abolish these volutitury schoola; and whatever we may think of the thoological reason for thatr atcablishment, their separate and practically Individuil mangewat does Incidentally afferd what ought to be, In any public

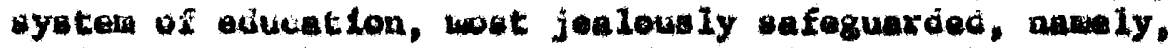
vartaty, and the opportuntey of experiment. What we heve to do with the voluntery schoole is to put the under the control of the lacal educational authority ... I

Balfour's ougsestion was:

Whether the schools in a dietrict were voluntaxy gr rate erected. . the locnl educetional authoritien / to be 7 created by the BLII would in the luture have aboolute control over all eccular education.2

Prorapty, H. Campbell-Bannerman, of the Opposition, rose to polnt out that if the BLII wore found to be mane only for securing speclal condderationi for the Church ochoole, ito chances of pasalng would not very great. Campell-Banaerman stated, however, that until the BLIl we printed he would reserve his judgement. 3

Probably no othar plece of leglalation in the twentlath century arouseà greater controversy. The bl11 took flfty-nine alght: of vigorous debst in Rarllament, and eifht monthe of political waneuvering In and outelde Whitehall culminatedng in the application of closure for Ite pareas in Dacembor, 1502.

In har alary, Beacxice Webb revenle the type of "parmentlon" practicad by the Fabians as they "wirepulled" both sidan of the House of Comone and Ided public optaton we we Durtng the peried of the

10o, clt., p. 14.

2yec. cle:

The A. B., p. 101. 
passage of the B111 through Parllawent, Beatrica's dlary contalne her personal obsarvations about the Education Bill and the Goverment officlals show the Wabba entertalnad tn thetr home at the the. For example, Bzatrice discloaes how she

took Prime Mintster (Arthur Balfour) ${ }^{1}$ into dianer . . Balfour has the chart: of genulne modesty and that evening he seened in earnest ebout edveation. . . I oet ayself to enuse and interest him, but seized every opportunity to inatnuate cound doctrine and Inforwation as to the position of Iondon education. 2

Alvo, Asquith when stuming the country, volced the oppostion's oplation of the BLII on revealed in the following axcerpt of a spech Aequith made at Alexandra Palaev duxing August, 1902, In cepany wth H. Compbe12-Bannerman. Asquith anld:

$I$ don't know the secret hletory of this / Fducation 7 B111- what was 1 ta pedigree, tho are 1 to real parents, where it firat wa the 11eht, who held it up to the tont- - I do not know my of these arcana of the LaglsLative Chanber. But this I do know, and thls I venture to ay to you, and to all falr-minied wen whom volce can resch, that if the object of the framars of thin $\mathbf{1 1 1}$ had baen to answer this question. 'At how low price, by how mall a currender of clexted and sectarian donlnation cen the Church of Eagland secure for all time to come for ber sehools a blank cheque upon the rates of Ingland and Wales?" this B1II is the siuplest and fullest anower to that inquiry. 3

At the very time of thl opabch, Beatrice notes the pace of "parmagtion" the Webbe vere pureulng: "Three dinner and twe evening partles at one's houe In elght deys 1, severe." Further, guest one of

IOn July 11, Lord Bailobury had Fornelly cesigneu as Prime Mintser, having waited until the peace settlenent in South Africa to do what he had lons cesirec. As a conwequance, Balfuns, who was Sallsbury'a nephew, was made Prime Minister on July 12, 1902.

2irake, p. 248 .

33. A. Bpendex and Cyxt1 Aqquith, life of Herbert Henxy Aequith, Lord Oxford and Aequiten (London: Lutchinson Co., 1S32), 701, I, p, 166 (av quoted therela). 
these dinners was Asquith, for Beatrlee noted that "Alquith. . . hav worked himself into an unxeal opposition to the Education B111. FAt dinner, Asquith 7 was sply dull. . . He is not really convinced of the Intquity or unisdow of the B111 he 10 denounc1ng."1

A tew ntght: latex, Butrice disclosen that "Worant dined here. . alone Fand 7 warled with the. . cempelgn, 2

Early In the oumoer, the Fabien Soclety took active support for the BA1L. This censisted of the printing of the resolutions wade by the seclety in ragard to the BLL1, and distributing these "documents by the thousadest to membere of Parlinment and mobrs of education cuthoritien "up and down the country." At the sane time the Iablans

Incesanty lectured and dobuted at Ifberal Aaseciatlons and Clube, and indelatigably worked the London and Previnetal presses; nong of the resourcen of okliful propagend Lets ves neglected witch might whake the oppostetion to the Blils, or convinee wese of the Libexal and Lbour oppomante thet for once at any rate a good ehlag wight cow exom the Conearvative Rarty.3

Indeed, the Fablan support of the Covernment BL11 substentiates their non-partisan philopephy, which contrabted wth the atand of Bryce whose work and anxllar findinge had centributed to whet was belag formulated. During the eacond reading of the B111, Bryce, in an uncompromtelng apeach, moved for the B111's rejection.

1 rerake, p. 249.

2The A. R., p. 137.

3. Ibid., p. 216 . 
It wes he mald, woat reactionary, and could not be accepted as even an instalmant of reform. The crention of a alngle education authorlty would be pald for too denrly by the extinction of the School Boards, which had done such admirable wrk; and in any case County counclis were not the bat authoricles for denling with elewentary educetion. Moreover,. . the B1Il falled to establioh undty of admintetrativa. . . The local manuger of Voluntery Schools would be virtually independent of the Educntion Condtce . . For eecondary education th B1I? would do Itttle, if anything.. . In fuct, he preferxed to cal1 Lt, not an zduegtion BL11, but a Voluntary Sehoolo Rallef BLIL. 1

Iv the onrly fall, agltation againet the B111 reuched a fevared pitch under the Inspiration of allitant Honcenformity, led by the Rovarend John Clifford, pector of the Westbourne Park Baptist Chapel and Dr. Robertion NLcol, editor of the Britteh Weekly. In an attempt to rally oupport, Clifford and MLCol ware careful not to treat their atteck as of concern to sonconformits, only, but atteapted to dras a compartoon with the attempt ande by Chuxles I, supported by Axcabiohop Laud, to obtain ship way without the authority of Yarllament. Alve, clifterd made en attempt to have the County Counc1le refuse to adrinLater the BII, and urged rate-payers to refuse to make paymente 2 S1dney Webb, at this time, "conducted a cklltul and acceasful carpalgn to defeat policy of pastue rastatanca' on the London County Counc11. In October, an article by Wabb, strongly supporting the B11, appeared in The Mlmeteanth Cancury and After, and tor a week Sidney Webb wote aditeridls supperting the 3112 for the Dally Mall.

Hest. A. B., 137.

${ }^{2}$ Ibld., p. 216.

${ }^{3 \text { Pease, D, } 147 .}$ 
The Fabians drafted thirteen amendmente for the B111's third reading; eleven of these mendments were adopted by the House of Comone and the Bill received the Royal asent on December $18 .^{1}$

Raxt I of the Education Act bore the Label, Local education authorities, alnce known as the I. B. A. S, bringing tnto law the

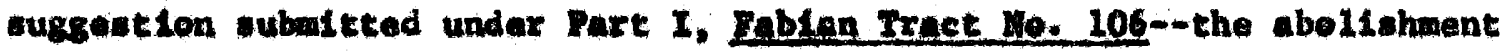
\$2 the schoel Bowds, and walns Instend, the elected, general purpoge County and County Borough Counclis the local autherites for education, as surcented in the tract.

The Act followed the tract sugsestion by making avallable to the veluntary shools, mosey from the locel rated an well as the antlonal towes. It was th1s, porhaps, thet ceused the grontest controveroy. "I thoupht," stdnay wrote in lattor yearo,

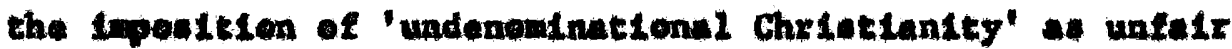
te the Jowe, Bnitarian, and Beculariate, an the imposteton of the Anglican Chureh Catielem on Reman Catholles and Moneon-

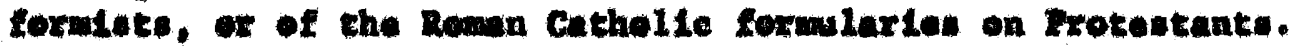
Noreover, I know that the reoult would be not the elosing of the Reran Catholic sehoole, but (a in the United states) thalx conthuance at private cast at a otill lover lovel of efflelaney, which vould be culeuttous for the very large and pexhype srowlag number of chlldron would reeort to then. Above al1, I wated to preserve vartety in education, xather than offictelly preseribed unf formlty--verlety in mothode of teaching, varlety in the subjecte saught, and varioty in 'atcouphere." I wanted to leuve the doox open to new and unthought-of experimente in the achoole.2

Parhape stdnay's greatest tricuph was that tha Act brought into being a nattond 1 yraten of education in Ingland

I Ibld.

2kurgaret Cole, Benkrice Webb, p. 83. 
Fwhich 7 is known as the 'educational ladder." It was now poestble for the claver child to pass from the - lewentaxy achool to the secondary chool with a cholarshtp or free plece--otherwloe moderate fees were charged--and then to the univer 1 ty. 1

Thus, what SIdnoy Wabb had effected for Iondon in 1893, wag accomp 119hed for Ingland with the passage of the 1902 sducation Act.

Pablan views nf the Act were sumarised in the opening paragraph of Tract No. 114, "The Education Act, 1902: How To Make The Best of It, 19sued Mnrch, 1903. It read:

Now, for the flrst time, education may be dealt with as a whole, without limltation or reatrictlon. The law in, oven now, far from satlofactory: . . But the local authoritien elected by the people can not provide as much education as they choose, up to whatever age they choose, of whitover kind thay choose, at auch fees we they choose, with a many and as valuable scholarships as they choose, whout aletinction of sex or rank or walth. On the -ther hand they ma, if they choose, provide no better schoole than the forater school board and bod1es of deneminational managere did, no more icholarahtpe than the forwar technical education conmittees did; they way eltogether neglect secondary and untversity education: In short, atthar in order to anve rates, or out of dislike of sows of the features of the lav, elther ixcal urudging the comon people any advancad education, warely through ignorance of the enormous powers and beneficlent opportunitias novly placed in thetr hande, the country coune 11 s and county borough councils may not only fall to provide cemplete educational gyeten, but actually use their power to prevent it. Popular control can never be raal unless it is given for better, for vorse. . . It is for the lectors to see that their represencat lves make the fullest posible use of the new powers, for the beucfit of the whole poople. 2

Thus, the Fablans, having performed their task of prossure politicking

1Jarman, p. 275.

2Fabian Tract No, 114, The Bducation Act of 1902: How to Make the Bat of It (London: The rabian Soc1ety, 1903), p. 2. 
as they saw it, cautioned the people that good laws are dependent on the electorate, indeed, enfranchisement requires responsibility. Generally, educational historians credit the Bill to Morant, but the above evidence indicates that there was considerable amount of Fabian preparation before Morant returned to England, especially the work done by Sidney Webb. Moreover, the "permeation" tactics indicate the political pressure that was exerted and applied in the right time and place to thwart the opposition. This rabianism. Indeed, the name of the Society was taken from that of the Roman general, Fabius Maximus, who attained imortality with his delaying tactics and methods of harrassment which thwarted the numerically superior troops of Hanniba1.

No doubt, Fablan influence amounted to very little among the reasons which caused the Conservatives to bring forward their Education B111; but the evidence is formidable that the Fabians cast a shadow over the events once the Conservatives decided to take action. 


\section{BIBLIOGRAPHY}

Public Documents

Great Britain. Hansard's Parliamentary Debates (3rd series). Vo1s. XX, XXIX, CXCIX.

U. S. Department of the Interfor. Report of the Commissionar of Education, 1902. Vo1. I (1903).

Books

Adamson, J. W. Eng1ish Education, 1789-1902. London: Cambridge University Press, 1930.

The Annual Register, A Review of Public Events at Home and Abroad for the Year 1902. London: Longmans, Green and Company, 1903.

Beer, Max. A History of British Socialism. New York: The Humanities Press, 1919.

Brogan, D. W. The English People: Impressions and Observations. New York: Alfred A. Knopf, 1948.

Cole, G. D. H., and Postgate, Raymond. The British Common People, 1746-1946. New York: Barnes and Noble, 1961.

Cole, Margaret, Beatrice Webb. London: Longmans, Green and Company, 1946.

Cole, Margaret. The Story of Fablan Soctalism. London: Mercury Books, 1961.

Cole, Margaret. The Webbs and Their Work. London: Frederick Muller, Ltd., 1949 .

Cramer, John Francis, and Browne, George Stephenson. Contemporary Education. New York: Harcourt, Brace and Wor1d, 1956.

Curtis, S. J., and Boultwood, M. E. A. An Introductory History of Education Since 1800. London: University Tutorial Press, Ltd., 1960. 
Drake, Barbara, and Cole, Margaret (eds.). Our Partnership by Beatrice Webb. London: Longmans, Green and Company, 1948.

Ensor, R. C. K. England 1870-1914. Oxford: At the Clexendon Press, 1949 .

Fremant1e, Anne. This Little Band of Prophets: The Britiah Rabians. New York: The Hew Amexican Libraxy, 1960.

Gardiner, A. G. Portralt and Portente. Now York: Harper Brother, 1926 .

Dent, H. C. The Educational Syatem of Bngland and Wales. London: University of London Press, 1961 .

Fisher, H. A. L. Jemea Bryce. New York: The Macmillan Company, 1927.

McBrlar, A. M. Eablan Soctallom and Englieh Follt1ce, 1884-1918. Cambridge: The Univeralty Fress, 1962.

Pease, Edward R. The Hiatory of the Tablan Society. 3rd ed. New York: Barnes and Woble, Inc., 1963.

Shaw, George, et al. Eabian Bssaye. 6th ed. London: George Allen and Unwin Ltd., 1962.

81mon, Brian. Studies in the Hidtory of Bducatlon, 1780-1870. London: Lawrence Wishart, 1960.

Sm1th, Frank. A Hietory of Englioh Elementery Bducetion, 1760-1902. London: Univeralty Preas, Led., 1931.

8atth, W. O. Education in Great Britain. London: Oxtord UnIvarsity Prese, 1958.

Spender, J. A., and Cyril Asquith. Life of Herbert Henry Asquith, Lord Oxford and Asquith. Vol. I. London: Hutchinson and Company, 1932 .

Tavney, R. H. The Webbs and Thelr Verk. London: Fablan Publications Limlted, n.d.

Trevelyan, G. M. HLtory of England. Vol. III: From utrecht to Modern IInes: The Industriel Revolution and the Iraneltion ko Democrecy. 3rd ed, reviued. Garden City, Now York: Doubleday and Company, 1956. 
Rexiodicals

"A Classtcal School and College Bducation," The Engl1eh Woman's Domestic Magasine, IX, No. 50 (June, 1864), 77-81.

"The Education Act of 1902: "Ow to Make the Best of It," Fablan Iract 110. 114, 1903.

"The Education Muddle and the Way Out," Rabian Tract Ho. 106, 1901.

Martin, J. W. "State Education at Home and Abroad," Rabian Tract No. 52.1894. 